\title{
PERBEDAAN KEMANDIRIAN ACTIVITY OF DAILY LIVING ANTARA PENDERITA LOW BACK PAIN INTENSITAS NYERI RINGAN DENGAN PENDERITA LOW BACK PAIN INTENSITAS NYERI SEDANG DI DESA SOBOKERTO KECAMATAN NGEMPLAK KABUPATEN BOYOLALI
}

\author{
Wawan Ridwan Mutaqin, Rina Kurnia \\ Kementerian Kesehatan Politeknik Kesehatan Surakarta Jurusan Okupasi Terapi
}

\begin{abstract}
Low Back Pain, Pain Intensity, ADL Independency Level. The research aimed to reveal the dissimilarity of $A D L$ independency on people with lower back pain (LBP) which varied from mild to moderate pain intensity. LBP means continuous pain which persists on the back side of the body span from lower ribs bone to coccyx bone and expand from upper back to the crotch. The research was comparing the level of independency in people with varied LBP intensity. The research conducted in Sobokerto, Ngemplak, Boyolali involving 50 respondents consisted of 25 respondents with mild pain intensity and 25 respondents with moderate pain intensity. Numeric Rating Scale (NRS) used as the research instrument to measure pain intensity and Barthel Index used as the tool to measure ADL independency level. The research designed is cross sectional and Mann Whitney $U$ were used as the analytical method. The data were analyzed with the use of SPSS 16 for windows. P value obtained as $0.000(<0.05)$ troughs the analytical test of Mann Whitney $U$. The research depicts clear evidence of different level on performing ADL independency in people with LBP within mild and moderate pain intensity.
\end{abstract}

Keywords: Low Back Pain, Pain Intensity, ADL Independency Level

Abstrak: Low Back Pain, Intensitas Nyeri, Kemandirian ADL. Penelitian ini
bertujuan untuk mengetahui apakah terdapat perbedaan kemandirian ADL pada
penderita Low Back Pain (LBP) dengan intensitas nyeri ringan dan intensitas
nyeri sedang. LBP yang dimaksud adalah nyeri di daerah punggung antara sudut
bawah kosta (tulang rusuk) sampai lumbosakral (tulang ekor), dan dapat menjalar
ke daerah lain seperti punggung bagian atas dan pangkal paha. Intensitas nyeri
yang dibandingkan adalah intensitas nyeri ringan dengan intensitas nyeri sedang
sehingga pada penelitian ini membandingkan kemandirian Activity of Daily Living
(ADL) pada penderita Low Back Pain (LBP) dengan intensitas nyeri ringan
dengan kemandirian Activity of Daily Living (ADL) pada penderita Low Back
Pain (LBP) dengan intensitas nyeri sedang. Penelitian ini dilakukan di Desa
Sobokerto Kecamatan Ngemplak Kabupaten Boyolali, dengan subjek penelitian
sebanyak 50 orang yang terdiri dari terdiri dari 25 orang sebagai kelompok
penderita LBP dengan intensitas nyeri ringan dan 25 orang sebagai kelompok
penderita LBP dengan intensitas nyeri sedang. instrument penelitian yang
digunakan adalah Numeric Rating Scale (NRS) untuk mengukur intensitas nyeri
pasien dan Barthel Indeks untuk mengukur kemandirian ADL. Desain penelitian
ini adalah cross sectional dan metode statistik yang digunakan adalah Mann 
Whitney U dengan bantuan program SPSS 16 for windows. Hasil uji Mann Whitney U diperoleh p value (nilai signifikansi) sebesar $0.000(<0.05)$. Penelitian ini menunjukkan bahwa terdapat perbedaan kemandirian ADL antara penderita LBP intensitas nyeri ringan dengan penderita LBP intensitas nyeri sedang.

Kata Kunci : Low Back Pain, Intensitas Nyeri, Kemandirian ADL

\section{PENDAHULUAN}

Low Back Pain (LBP) sering dijumpai dalam praktek sehari-hari, terutama di negara-negara industri. Diperkirakan 70-85\% dari seluruh populasi pernah mengalami episode ini selama hidupnya (Sadeli, 2001).

Faktor resiko LBP meliputi faktor resiko kerja dan faktor resiko non kerja, antara lain riwayat mengendarai kendaraan, olahraga, merokok dan kehamilan. Pasien baik laki-laki maupun wanita dengan LBP ditemukan bahwa mereka secara signifikan melakukan aktivitas secara berlebihan memindahkan beban, mengangkat beban, membawa beban, mendorong, menarik, membungkuk dan bekerja dengan badan selalu berputar. LBP lebih sering diderita oleh laki-laki dengan usia yang lebih tua dibandingkan dengan laki-laki yang lebih muda. Kemudian banyak dari supir truk yang menderita low back pain. Pada wanita yang sering hamil lebih beresiko menderita LBP (Strong, 1996).

Individu dengan LBP dapat mengalami nyeri yang bervariasi mulai dari ringan sampai berat dan dapat berlangsung dalam jangka waktu pendek atau panjang. Namun yang terjadi, LBP dapat membuat kegiatan sehari-hari sulit dilakukan (AAOS, 2009).

Ada pasien yang secara fisik tidak mampu melaporkan nyeri secara verbal, sehingga harus diamati perilaku nonverbal yang dapat terjadi bersama nyeri. Terdapat 4 atribut pasti dalam pengalaman nyeri yaitu : nyeri bersifat individu, tidak menyenangkan, merupakan suatu kekuatan yang mendominasi dan bersifat ketidaksudahan (Mahon, 1994 dalam Potter \& Perry, 2005).

Activity of daily living (ADL) pada penderita nyeri akan mengalami gangguan, pada umumnya mereka menghindari untuk mengerjakan ADL karena menghindari nyeri (Reed, 1991).

Desa Sobokerto Kecamatan Ngemplak Kabupaten Boyolali merupakan desa yang penduduknya sebagian besar bermata pencaharian sebagai buruh, pekerja berat dan penduduk wanita banyak yang sehariharinya berjualan di pasar dengan menggendong "tenggok". Berdasarkan hal tersebut maka dimungkinkan banyak penduduk Sobokerto yang mengalami keluhan LBP. Dan sepengetahuan peneliti, belum pernah dilakukan penelitian tentang LBP di Desa Sobokerto.

\section{METODE PENELITIAN}

Desain penelitian dalam penelitian ini adalah cross sectional dilakukan dengan membandingkan kemandirian ADL pada penderita LBP dengan intensitas nyeri ringan dengan kemandirian ADL pada penderita LBP dengan intensitas nyeri sedang.

\section{HASIL PENELITIAN}

Data kemandirian ADL diukur dengan Barthel Indeks yang dengan interpretasi menurut Shah (1989) 
sebagai berikut: 0 - 20 ketergantungan total, 21 - 60 ketergantungan berat, 61 90 ketergantungan sedang, 91 - 99 ketergantungan ringan, 100 mandiri. Pada kelompok penderita LBP dengan intensitas nyeri ringan mempunyai kemandirian ADL mandiri. Dapat dilihat pada tabel berikut ini :

\begin{tabular}{ccc}
\hline Remandinizan ADL & Jumlah & Prosentase \\
\hline Nandidi & 25 & 100 \\
\hline Total & 25 & 100 \\
\hline
\end{tabular}

Pada kelompok penderita LBP dengan intensitas nyeri sedang kemandirian ADL bervariasi meliputi : mandiri, ketergantungan ringan, ketergantungan sedang dan ketergantungan berat. Jumlah paling banyak adalah mandiri dengan total 10 orang atau $40 \%$ dan jumlah paling sedikit adalah ketergantungan ringan dengan total 4 orang atau $8 \%$. Dapat dilihat pada tabel berikut ini :

\begin{tabular}{ccc} 
Kemandirian ADL & Jumlah & Prosentase \\
\hline Mandiri & 10 & 40 \\
Ketergantungan ingan & 4 & 16 \\
Ketergantungan sedang & 5 & 20 \\
Ketergantungan berat & 6 & 24 \\
\hline Total & 25 & 100 \\
\hline
\end{tabular}

Hasil uji Mann Whitney U pada kelompok penderita LBP dengan intensitas nyeri ringan dan kelompok penderita LBP dengan intensitas nyeri sedang diperoleh $\mathrm{p}$ value (nilai signifikansi) sebesar $0.000 \quad(<0.05)$ yang berarti terdapat perbedaan kemandirian ADL antara penderita LBP intensitas nyeri ringan dengan penderita LBP intensitas nyeri sedang.

\section{PEMBAHASAN}

Terdapat perbedaan kemandirian ADL pada kelompok LBP intensitas nyeri ringan dengan kelompok LBP intensitas nyeri sedang. Dari karakteristik responden berdasarkan kemandirian ADL dapat diketahui bahwa seluruh responden kelompok penderita LBP dengan intensitas nyeri ringan mempunyai kemandirian $\mathrm{ADL}$ mandiri. Dan pada kelompok penderita LBP dengan intensitas nyeri sedang kemandirian ADL bervariasi meliputi : mandiri, ketergantungan ringan, ketergantungan sedang dan ketergantungan berat. Dari hasil tersebut dapat diketahui bahwa kemandirian antara kedua kelompok adalah berbeda.

Menurut hasil penelitian ini, perbedaan intensitas nyeri berpengaruh pada perbedaan kemandirian ADL, semakin tinggi intensitas nyeri maka kemandirian ADL semakin menurun. Hal tersebut didukung oleh penelitian McGorry (2000) bahwa penderita LBP kronis dengan intensitas nyeri tinggi secara signifikan mengalami keterbatasan aktifitas fungsional yang lebih berat dibandingkan dengan intensitas nyeri rendah. Hal tersebut juga sesuai dengan penelitian oleh Shonafi (2011) bahwa terdapat korelasi antara intensitas nyeri dengan disabilitas aktivitas sehari-hari pada pasien nyeri punggung bawah (NBP), semakin tinggi intensitas nyeri akan diikuti juga dengan peningkatan pada disabilitas aktivitas sehari-hari.

Hasil penelitian ini sama dengan penelitian yang dilakukan oleh Shonafi (2011) dengan judul "Hubungan Antara Intensitas Nyeri dengan Disabilitas Aktivitas Sehari-hari pada Pasien Nyeri Punggung Bawah (NBP) di RSUD Dr. Moewardi". Pada penelitian tersebut didapatkan hasil bahwa terdapat hubungan antara intensitas nyeri dengan disabilitas aktivitas sehari-hari pada pasien nyeri punggung bawah (NBP) di RSUD Dr. Moewardi, hal ini berarti jika 
terdapat peningkatan intensitas nyeri akan diikuti juga dengan peningkatan pada disabilitas aktivitas sehari-hari. Perbedaannya dengan penelitian ini yaitu pada penelitian Shonafi (2011) hanya melihat hubungan intensitas nyeri dengan disabilitas aktivitas sehari-hari tanpa membedakan intensitas nyeri sedangkan pada penelitian ini melihat pada perbedaan intensitas nyeri terhadap kemandirian ADL. Hasil penelitian ini juga sama dengan penelitian yang dilakukan oleh Kambodji (2003) dengan judul "Pengaruh Intensitas Nyeri terhadap Keterbatasan Fungsional Aktivitas Sehari-hari Penderita Nyeri Punggung Bawah Kronis". Pada penelitian tersebut didapatkan hasil bahwa keterbatasan fungsional aktivitas sehari-hari dipengaruhi oleh intensitas nyeri, nyeri yang diperberat oleh batuk, status pengobatan dan pemeriksaan Leseque. Perbedaannya dengan penelitian ini yaitu pada penelitian oleh Kambodji (2003) merupakan penelitian experimental untuk mengetahui pengaruh intensitas nyeri terhadap keterbatasan fungsional aktivitas seharihari penderita nyeri punggung bawah kronis, sedangkan pada penelitian ini merupakan penelitian non experimental untuk mengetahui perbedaan kemandirian ADL pada kelompok LBP intensitas nyeri ringan dengan kelompok LBP intensitas nyeri sedang.

\section{KESIMPULAN DAN SARAN}

Pada penelitian ini jumlah responden 50 orang yang terdiri dari 25 responden kelompok penderita LBP intensitas nyeri ringan dan 25 responden kelompok penderita LBP intensitas nyeri sedang.

Berdasarkan hasil analisis data pada penelitian ini maka dapat disimpulkan bahwa terdapat perbedaan kemandirian ADL antara penderita LBP intensitas nyeri ringan dengan penderita LBP intensitas nyeri sedang dengan nilai $\mathrm{p}$ sebesar 0.000 .

\section{DAFTAR RUJUKAN}

Kambodji, J. (2003). Pengaruh Intensitas Nyeri Terhadap Keterbatasan Fungsional Aktivitas Sehari-hari Penderita Nyeri Punggung Bawah Kronis, Suplemen Berkala Neurosains, pp: $129-38$

McGorry R.W. (2000). The relation beween pain intensity, disability, and the episodic nature of chronic and recurrent low back pain, Spine No.25(7), pp: 834-41.

Potter, P.A. \& Perry, A.G. (2005). Buku Ajar Fundamental Keperawatan : Konsep Proses \& Praktis Edisi 4 Volume 2. Jakarta : EGC

Reed, K.L. (1991). Quick Reference To Occupational Therapy. Maryland : Aspen Publishers, Inc.

Shonafi, K.A. (2011). Hubungan Antara Intensitas Nyeri dengan Disabilitas Aktivitas Sehari-hari pada Pasien Nyeri Punggung Bawah (NBP) di RSUD Dr. Moewardi. Retrieved November, 22, 2012, dari library.ums.ac.id

Strong, J. (1996). Chronic Pain the Occupational Therapist's Perspective. Churchill Livingstone : Medical Division of Pearson Professional Limited 